\title{
Effects of brazing parameters on the microstructure and tensile shear force of copper sheets using amorphous filler metal
}

\author{
Prajak Jattakul and Kannachai Kanlayasiri* \\ Industrial Engineering Department, Faculty of Engineering, King Mongkut's Institute of Technology Ladkrabang, Bangkok, Thailand
}

\begin{abstract}
In this research, the objective was to investigate and measure the microstructure, tensile shear force, and fracture surface behavior when copper sheets are brazed using $\mathrm{Cu}-\mathrm{Ni}$-Sn-P amorphous filler metal. In order to examine the microstructure and its properties, assessment of the $\mathrm{Cu}-\mathrm{Ni}-\mathrm{Sn}-\mathrm{P} / \mathrm{copper}$ brazed joints was conducted after furnace brazing under an argon atmosphere using specific parameters relating to temperature, holding time, and loading pressure. In order to assess the tensile shear force, tensile testing was carried out. All the joints exhibited sound bonding without voids or cracks, when brazing temperatures reached $680{ }^{\circ} \mathrm{C}$, this resulted in a maximum value for tensile shear force of $696.325 \mathrm{~N}$. The microstructure consisted of both $\mathrm{Cu}$-rich solid solution and $\mathrm{a}(\mathrm{Cu}, \mathrm{Ni})_{3} \mathrm{P}$ phase as a eutectic structure formed in the brazing joint, and then the $\mathrm{Cu}$-rich solid solution was produced as a matrix region around the eutectic structure. Fracture analysis was conducted for brazed joints which showed the ductile fractures after the shear test.
\end{abstract}

\section{Introduction}

Today there are numerous industrial applications for devices which employ both micro-channel process technology (MTP) and laminated micro-channel array (LMA). These include the conversion of natural gas to liquid form, the recovery of waste heat, and thermal management of laser diodes. While it is possible for large MPT devices to be constructed, with dimensions measured in meters, they include microchannel components in sizes measuring as little as $100 \mu \mathrm{m}[1,2]$. The most notable advantage offered by MPT devices over the conventional technologies is the large surface area to volume ratio, which permits much faster transfers of heat and mass inside the microchannels on account of the shortened distances over which diffusion takes place. The consequence is that the microchannels are able to generate energy and chemical systems which are both smaller and lighter [3].

Typically, there are three key stages in the process of micro-lamination. These comprise laminate registration, patterning, and bonding. The bonding process is usually conducted via soldering, diffusion brazing, diffusion bonding, or fusion joinings [4,5]. In the soldering process this method requires a low joining temperature and short joining time, however suffers from a weaker joint and fluid stage emerges in the joining process and is unsatisfactory for high-temperature applications [6,7]. In the case of diffusion bonding and diffusion brazing, these techniques create a strong joint but require a high welding temperature and extended welding time, giving rise to the high production cost [8]. The ultrasonic welding process, requires a short joining time but yields low joint strength and is unsuited for high-temperature applications [9-12].
In the case of fusion weldings, such as electron beam welding and tungsten inert gas welding, the sheets are joined together only at the edges, such that the microchannels are not tight to each other leading to mixing of the medium fluid [13]. Amongst them, brazing has been taken into consideration to be one of the optimal joining techniques due to its high joint strength, simplicity, low expenses, as well as a vast variety of filler metals $[14,15]$.

This study performs the brazing of copper sheets using $\mathrm{Cu}-\mathrm{Ni}$-Sn-P amorphous filler metal, whereby the particular point of interest lies in the characteristics of the microstructure and the tensile shear force of the joints when different brazing temperatures are used.

\section{Experiment process}

\subsection{Materials preparation}

The base material employed in the brazing process was commercially pure copper sheet, with thickness of 0.350 $\mathrm{mm}$. The samples were divided into rectangular plates with $10 \times 26.25 \times 0.35 \mathrm{~mm}$ dimensions. The filler metal was $\mathrm{Cu}-\mathrm{Ni}-\mathrm{Sn}-\mathrm{P}$ amorphous ribbon and its thickness was about $0.025 \mathrm{~mm}$. In the experiment, rectangular plates of the filler metal were cut to a size of $2 \times 10 \times 0.025 \mathrm{~mm}$. Furnace brazing was carried out using a CARBOLITE No. 20-600024 model. The brazing process was performed under an argon atmosphere to protect the specimens from oxidation.

*Corresponding author: kannachai.ka@ kmitl.ac.th 


\subsection{Brazing process}

The joints of the foil and the copper sheets were then affixed between two copper sheets using a brazing fixture. The loading pressure was then set to $30.433 \mathrm{kPa}$ and an argon atmosphere used for the furnace brazing at a variety of brazing temperatures. Initially, the heating of the brazing couple was carried out in order to reach the brazing temperature, with the increase in temperature progressing at $10{ }^{\circ} \mathrm{C} / \mathrm{min}$. The various brazing temperatures used were $600{ }^{\circ} \mathrm{C}, 640{ }^{\circ} \mathrm{C}, 660{ }^{\circ} \mathrm{C}$, and 680 ${ }^{\circ} \mathrm{C}$ while the holding time was 5 minutes. At last, the furnace was cooled down to room temperature. In this study, each brazing condition was performed twice to ensure the result.

\subsection{Microstructure observation and mechanical testing}

Upon completion of the brazing, the joints were cut along their length, before grinding using an abrasive paper and polishing using alumina powder at $1 \mu \mathrm{m}$ and $0.3 \mu \mathrm{m}$. Following the brazing process, the microstructure was examined and the element composition of the brazing joints was assessed using SEM (JEOL model JSM6610LV, Japan). An EDS (Inca, Oxford, UK) was also employed for the analysis. The test to measure the tensile shear force at the brazed joints was performed at regular room temperature using a Shimadzu AG-100 universal testing machine with a crosshead speed of $0.1 \mathrm{~mm}$ per minute.

\section{Results and discussion}

\subsection{Microstructure analysis of brazed joints}

The first experiment involved the brazing at $680{ }^{\circ} \mathrm{C}$ for 5 minutes of amorphous $\mathrm{Cu}-\mathrm{Ni}-\mathrm{Sn}-\mathrm{P}$ BFM, while the loading pressure was set at $30.433 \mathrm{kPa}$. Fig. 1(a-b) presents the backscattered electron image showing the cross section of the $\mathrm{Cu} / \mathrm{Cu}-\mathrm{Ni}-\mathrm{Sn}-\mathrm{P} / \mathrm{Cu}$ joint. It is clear that there are no cracks or voids to be seen at the joint, indicating that the mechanical properties should suffer no weaknesses. The brazed zone has a width exceeding that of the original joint clearance, measuring around $40 \mu \mathrm{m}$, since the interaction between the base material and BFM occurs via the base material solution containing the liquid filler alloy, while diffusion occurs as both liquid and solid. The brazed zone can be separated into two separate reaction zones (I and II: Fig. 1(a)) on the basis of the chemical composition and the microstructural morphology. There are two phases in the brazed zone, marked as A and B (Fig. 1(b-d)). Phase A is shown in light gray while phase $\mathrm{B}$ is dark gray. Phase $\mathrm{A}$ is the major phase and is located adjacent to the base alloy, while phase B can be seen within the intergranular area of phase $\mathrm{A}$ at the middle of the brazed zone. The microstructure of $\mathrm{Cu} / \mathrm{Cu}-\mathrm{Ni}-\mathrm{Sn}-\mathrm{P} / \mathrm{Cu}$ joint mainly comprised the eutectic phase on the brazed zone, as shown in Fig. 2(a-f) presenting the backscattering electron image and quantitative phase compositions of the eutectic phase in the brazed seam. It can be seen that there were $(\mathrm{Cu}, \mathrm{Ni})_{3} \mathrm{P}$ and $\mathrm{Cu}$-rich phases in the eutectic structure labeled by point $\mathrm{A}$ and $\mathrm{B}$. Element analysis of the brazed zone by EDS and x-ray mapping showed that the major element found in the two phases in $\mathrm{Cu}$, as indicated in Fig. 2(a-f) and Table 1 .

Table 1. The compositions of the marked zones from Fig. 1(b).

\begin{tabular}{|c|c|c|c|c|c|}
\hline \multirow{2}{*}{ Position } & \multicolumn{4}{|c|}{ Eutectic composition (at. \%) } & \multirow{2}{*}{$\begin{array}{c}\text { Possible } \\
\text { phase }\end{array}$} \\
\cline { 2 - 5 } & $\mathrm{Cu}$ & $\mathrm{Ni}$ & $\mathrm{Sn}$ & $\mathrm{P}$ & \\
\hline A & 95.06 & - & 4.94 & - & $\mathrm{Cu}$ Rich \\
\hline B & 36.05 & 37.69 & 0.31 & 25.96 & $(\mathrm{Cu}, \mathrm{Ni})_{3} \mathrm{P}$ \\
\hline
\end{tabular}
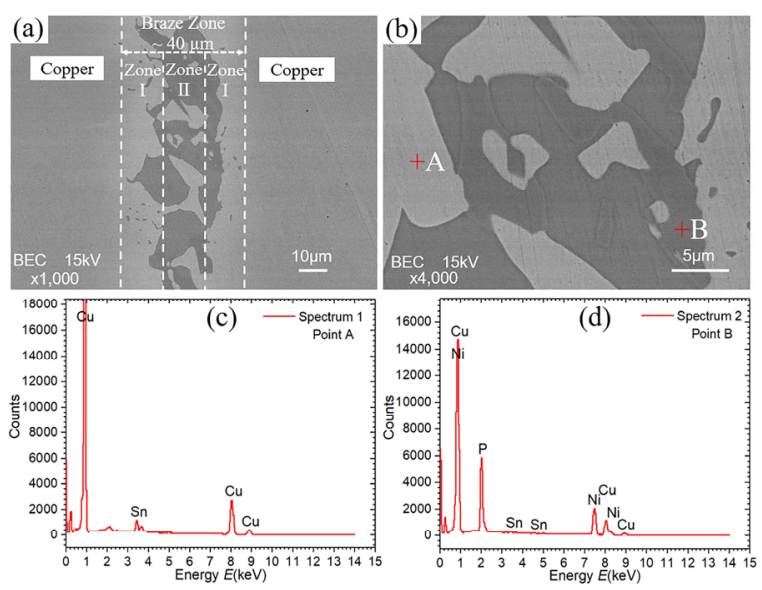

Fig. 1. (a-b) Brazed joint morphology of a brazed joint under conditions of $680^{\circ} \mathrm{C}, 5$ minutes, and $30.433 \mathrm{kPa}$, (c-d) EDS spectrum of point $\mathrm{A}$ and $\mathrm{B}$, respectively.
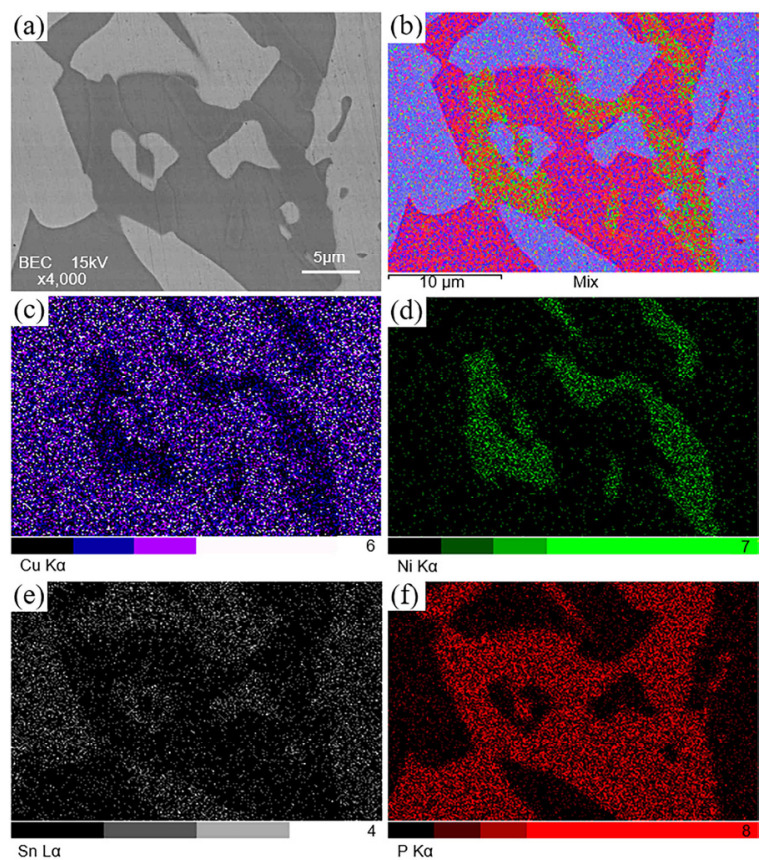

Fig. 2. (a) The interfacial microstructure of $\mathrm{Cu} / \mathrm{Cu}-\mathrm{Ni}-\mathrm{Sn}-\mathrm{P} / \mathrm{Cu}$, (b) the x-ray mapping for $\mathrm{Cu}, \mathrm{Ni}, \mathrm{Sn}$ and $\mathrm{P}$ (c) $\mathrm{Cu} \mathrm{K} \alpha$ mapping, (d) Ni K $\alpha$ mapping, (e) Sn L $\alpha$ mapping, (f) P K $\alpha$ mapping. 
The EDS findings are shown in Fig. 2 and Table 1 as compositional maps illustrating the brazed joint. In this format, it is possible to determine the spatial distribution of the elements; it is thus clear that within the joint there is a continuous $\mathrm{Cu}$-rich phase along with a $(\mathrm{Cu}, \mathrm{Ni})_{3} \mathrm{P}$ phase. By considering the atomic ratio of the microstructure of the brazed joint microstructure in addition to the binary $\mathrm{Cu}-\mathrm{P}$ phase diagram, it may be inferred that there exist both $\mathrm{Cu}_{3} \mathrm{P}$ and $\mathrm{CuP}_{2}$ phases in the reaction layer [16]. This study did not, however, record any sign of a $\mathrm{CuP}_{2}$ phase being formed at the brazed joint. The binary phase diagram of $\mathrm{Cu}-\mathrm{Ni}$ and $\mathrm{Cu}-\mathrm{Sn}$ (at $\mathrm{Sn} 4.94$ at. \%) indicates the absence of an intermetallic phase, thereby revealing that a solid solution was produced by $\mathrm{Cu}-\mathrm{Ni}$ and $\mathrm{Cu}-\mathrm{Sn}$. This demonstrates conclusively that it is possible for the brazing process to be completed without generating an intermetallic phase. When producing $(\mathrm{Cu}$, $\mathrm{Ni})_{3} \mathrm{P}$, this was achieved using filler metal containing nickel and phosphorus atoms diffused in the direction of the interface, while the base material contained copper atoms which also diffused in the direction of the interface, thereby creating the observed $(\mathrm{Cu}, \mathrm{Ni})_{3} \mathrm{P}$ compound.
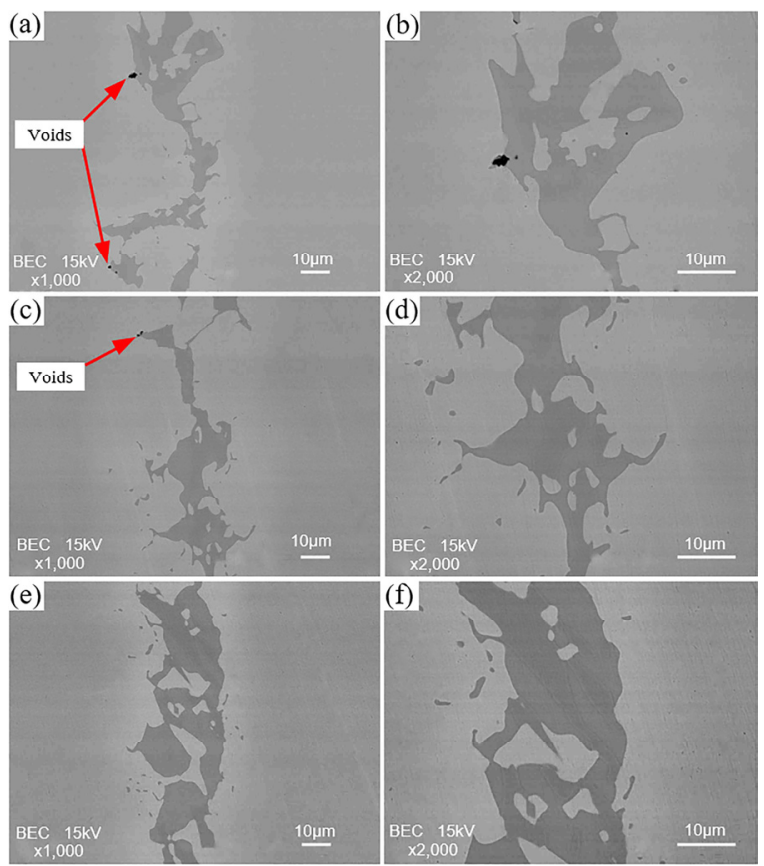

Fig. 3. The backscattered electron image showing the morphology of the cross-section of the $\mathrm{Cu} / \mathrm{Cu}-\mathrm{Ni}-\mathrm{Sn}-\mathrm{P} / \mathrm{Cu}$ brazed joint using 5 minutes holding time and a loading pressure of $30.433 \mathrm{kPa}$ with amorphous $\mathrm{BFM}$ at varying brazing temperatures of: (a-b) $640{ }^{\circ} \mathrm{C}$, (c-d) $660{ }^{\circ} \mathrm{C}$ and (e-f) $680{ }^{\circ} \mathrm{C}$.

Fig. 3(a-f) indicated the microstructure morphologies of the microstructure of $\mathrm{Cu} / \mathrm{Cu}-\mathrm{Ni}-\mathrm{Sn}-\mathrm{P} / \mathrm{Cu}$ joints at both low and high magnification when brazed at varying temperatures of $640{ }^{\circ} \mathrm{C}, 660{ }^{\circ} \mathrm{C}$, and $680{ }^{\circ} \mathrm{C}$ in an argon atmosphere furnace for 5 minutes at $30.433 \mathrm{kPa}$. Fig. 3(b, $\mathrm{d}, \mathrm{f}$ ) shows the microstructure of the brazed zone in high magnification and also indicates the eutectic phase for the various different brazing temperatures. The difference in image contrast shows that the brazed zone is a mixed region comprising two phases. Examination revealed that there were micro-voids to be found between the filler metal and the copper substrate, leading to doubts about the efficiency of the joint. Fig. 3(a-b) depicts this particular issue. The reason for this shortcoming is that at relatively low brazing temperatures $\left(640^{\circ} \mathrm{C}\right.$ for $5 \mathrm{~min}$ and $30.433 \mathrm{kPa}$ ), the filler is unable to completely react with the copper sample in order to form a continuous reaction layer. This issue can, however, be resolved by increasing the temperature $\left(660{ }^{\circ} \mathrm{C}\right.$ for $5 \mathrm{~min}$ and $\left.30.433 \mathrm{kPa}\right)$, whereupon the voids are minimized and a continuous reaction layer can be clearly identified. Fig. 3(c-d) shows this variation. Finally, upon further increasing the temperature $\left(680^{\circ} \mathrm{C}\right.$ for $5 \mathrm{~min}$ and $\left.30.433 \mathrm{kPa}\right)$, no cracks at all can be observed, as indicated in Fig. 3(e-f).

\subsection{Mechanical properties brazed joint}

Fig. 4 indicates how the different brazing temperatures influence the joint strength after brazing with $\mathrm{Cu}-\mathrm{Ni}-\mathrm{Sn}-\mathrm{P}$ amorphous BFM. The findings revealed that when brazing takes place for 5 minutes at $600{ }^{\circ} \mathrm{C}$ at $30.433 \mathrm{kPa}$, the maximum joint strength recorded was $352.526 \mathrm{~N}$. Increasing the temperature to $640^{\circ} \mathrm{C}, 660{ }^{\circ} \mathrm{C}$, and finally $680{ }^{\circ} \mathrm{C}$ caused further increases in the joint strength to 696.325 N, with the improvement showing a similar pattern to that observed in the tensile shear force test. Furthermore, Fig. 4 also confirms that when the brazing temperature is insufficient, a strong joint with good bonding cannot be achieved. At the maximum temperature for this study, of $680{ }^{\circ} \mathrm{C}$, a strong joint could be formed.

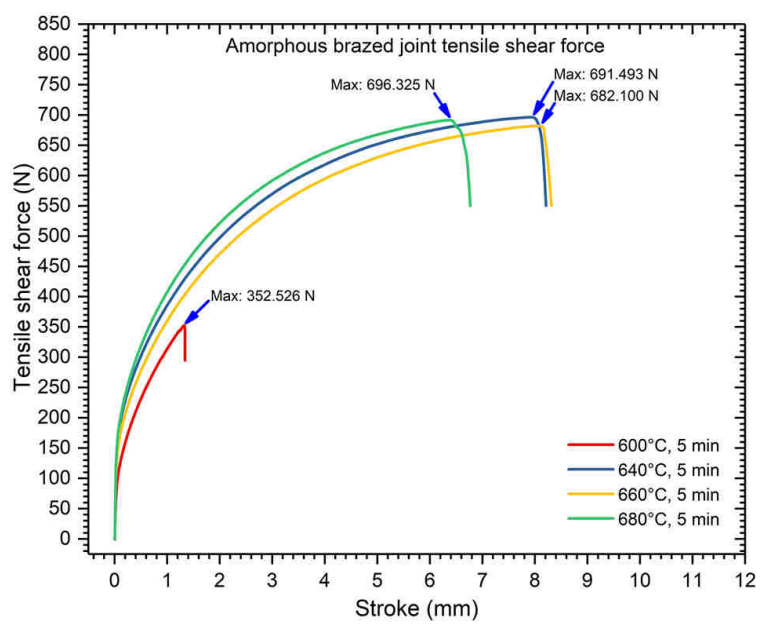

Fig. 4. Effect of brazing temperature on joint strength.

\subsection{Fracture characteristics of brazed joints}

Fracture analysis was carried out using SEM to establish the fracture mode. The findings are shown in Fig. 5(a-b) which presents an overview along with magnified images of the specimen fracture surfaces following brazing at 600 ${ }^{\circ} \mathrm{C}$ upon completion of the shear tests. Cleavage steps are observed on the fracture surface (Fig. 5(a-b)), suggesting the dimples fracture mode of the joint, as denoted in the 
mark line in Fig. 5(a). The formation of the dimples implies plastic deformation in the micro-regions, which is sometimes taken as a positive indication of enhancement of the mechanical properties of the joint, According to these results, the improvement of the $\mathrm{Cu} / \mathrm{Cu}-\mathrm{Ni}-\mathrm{Sn}-\mathrm{P} / \mathrm{Cu}$ brazed joint was achieved because the formation of ductile dimple fracture resulted from the strong bonding and fatigue resistance, and when the brittle fracture formation occurred on the brazing joints, the cracks preferred to propagate at the brittle intermetallic compounds, resulting in an easy propagation of the cracks, which leads to a decrease in the strength and fatigue life of the joints [17]. Fig. 5(b), shows a large number of dimples densely distributed on the fracture surface, which is a typical feature of ductile failure. According to these results, it is suggested that the fracture mode of the joint is a ductile fracture mode.

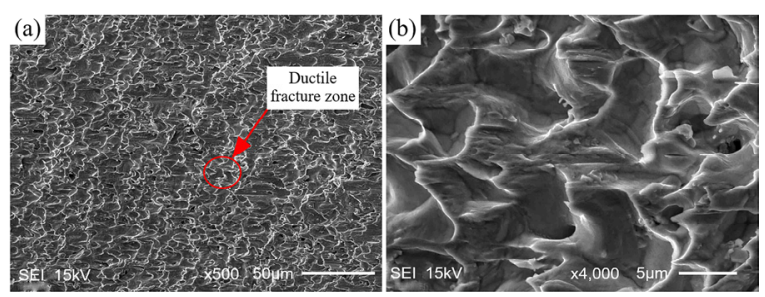

Fig. 5. Fracture morphologies of the $\mathrm{Cu} / \mathrm{Cu}-\mathrm{Ni}-\mathrm{Sn}-\mathrm{P} / \mathrm{Cu}$ brazed joint after shear tests: (a) overall view; (b) magnified views of the ductile fracture zone.

\section{Conclusions}

The current study assessed the properties and microstructure of the brazed joints between copper sheets and $\mathrm{Cu}-\mathrm{Ni}-\mathrm{Sn}-\mathrm{P}$ amorphous filler metal. The major conclusions are summarized as follows:

(1) Solid joints without micro-pores or any defects in the brazed joint were obtained when the brazing temperature increased to $680{ }^{\circ} \mathrm{C}$, the highest value achieved for the tensile shear force was $696.325 \mathrm{~N}$.

(2) The of $\mathrm{Cu} / \mathrm{Cu}-\mathrm{Ni}-\mathrm{Sn}-\mathrm{P} / \mathrm{Cu}$ brazed joint consisted of $\mathrm{Cu}$-rich phase and the eutectic structure formed the phases in eutectic region were $\mathrm{Cu}$-rich solid solution and $\mathrm{a}(\mathrm{Cu}, \mathrm{Ni})_{3} \mathrm{P}$ phase.

(3) Analysis of all the fractured surfaces of the brazed joints revealed ductile fracture characteristic upon completion of the shear test.

\section{Acknowledgements}

The researchers are grateful to King Mongkut's Institute of Technology Ladkrabang in acknowledgement of the financial support offered for this study.

\section{References}

1. K. Kanlayasiri, B.K. Paul, J. Manuf. Process. 672 80 (2004).

2. J. Li, S. Wang, W. Cai, W. Zhang, Appl. Therm. Eng.
30 2738-2745 (2010).

3. P. Paulraj, B.K. Paul, R.B. Peterson, Appl. Therm. Eng. 48 194-201 (2012).

4. R. Eluri, B. Paul, J. Manuf. Process. 14 471-477 (2012).

5. T. Watanabe, H. Sakuyama, A. Yanagisawa, J. Mater. Process. Technol. 209 5475-5480 (2009).

6. B.K. Paul, N. Sharma, T. Doolen, J. Manuf. Process. 7 174-181 (2005).

7. P. Paulraj, B.K. Paul, J. Manuf. Process. 13 85-95 (2011).

8. R. Eluri, B.K. Paul, Mater. Des. 36 13-23 (2012).

9. M. Shakil, N.H. Tariq, M. Ahmad, M.A. Choudhary, J.I. Akhter, S.S. Babu, Mater. Des. 55 263-273 (2014).

10. S. S. Lee, T.H. Kim, S.J. Hu, W.W. Cai, J.A. Abell, J. Manuf. Sci. Eng. 137 31016-1-8 (2015).

11. J.S. Seo, H.S. Jang, D.S. Park, Mater. Manuf. Process. 30 1069-1073 (2015).

12. M.P. Satpathy, B.R. Moharana, S. Dewangan, S.K. Sahoo, Eng. Sci. Technol. Int. J. 18 634-647 (2015).

13. W.W. Basuki, O. Kraft, J. Aktaa, Mater. Sci. Eng. A 538 340-348 (2012).

14. J. Zou, Z. Jiang, Q. Zhao, Z. Chen, Mater. Sci. Eng. A 507 155-160 (2009).

15. P. Jattakul, K. Kanlayasiri, ICMM, International Conference on Mechatronics and Manufacturing (2018)

16. H. Okamoto, P.R. Subramanian, L. Kacpzak, T.B. Massalski, Binary Alloy Phase Diagram (The Materials Information Society, 2001).

17. E. Ganjeh, H. Sarkhosh, M.E. Bajgholi, H. Khorsand, M. Ghaffari, Mater. Charact. 71 31-40 (2012). 